\title{
13
}

\section{The media and the spectre of the 2000 coup}

\section{Michael Field}

A green prison truck pulls into the crowded alleyway behind the old government buildings in downtown Suva. A handful of photographers and reporters try to catch a glimpse of a ghost riding in the back. George Speight. Almost exactly to the day six years before - 19 May 2000 - accompanied by special forces soldiers, he had charged on to the floor of parliament and seized Prime Minister Mahendra Chaudhry and his government. Although he now whiles away a pleasant, if dull, life on Nukulau as a convicted traitor, Speight's before-election appearance - such as it was - had nothing to do with the balloting. Rather, as a witness this time, Speight was part of the seemingly endless post-coup wash-up that Fiji and its interminable justice system just cannot throw.

A little earlier, and across the road, a mellow Sitiveni Rabuka had sat by a window at the Holiday Inn restaurant having breakfast. He too had been in court, although as a defendant, facing a charge of inciting mutiny in the Fiji military. In earlier times, conviction on such a charge would have led to a firing squad; these days it is life imprisonment - but Rabuka was calm. Having spent six weeks in India having knee replacement surgery, he was keen to talk about Mahatma Gandhi and India's political system. 'Minorities hold all the top positions in India', he says. 'The president is a Muslim, the Prime Minister and the military chief are both Sikhs and the head of the largest political party, Congress, is Italian.' 
It could have been an odd conversation, given that, in 1986, Rabuka had seized power to overthrow the newly elected Indian-dominated government and was one of the founding prophets of Taukei, or indigenous rule. That it was not so unusual has much to do with the way in which post-independence Fijian political life, while obviously polarized, is still very much in the formative stages. History too is very compressed: the kind of events that elsewhere might have taken place over a century or more, in Fiji have occurred over the two decades since 1987. That Rabuka should become an advocate of Indian political processes is entirely natural in the context of Fiji. While racial and cultural divisions are mostly seismic in Fiji, with both sides well apart, refreshingly one also finds characters seemingly quite happy to live and partake of a multicultural Fiji.

At one level, it is kind of comforting: Fiji can get through these things. But at another, the whole air of uncertainty is distinctly destabilizing, and as Fiji moved into its elections in 2006, the whole sense of unfinished business created unease. Both Rabuka and Speight were, at the candidate and party level, an irrelevancy; but among voters and the media covering the election they were ghosts to be noticed. There was, though, another coup plotter, although he does not see himself that way: Republic of Fiji Military Forces head Commodore Voreqe Bainimarama. His view of himself as the nation's saviour, and his refusal to acknowledge that his behaviour in 2000 was unconstitutional, meant that the 2006 election had to be conducted with an eye to what the man with the guns was saying and doing. Any comfort anybody might have drawn from his statements on good order soon evaporated under the heat of his immoderate and erratic behaviour. It was hard to pick what he might do.

Rabuka’s first coup, 14 May 1987, was in a pre-digital age (one of the last big Pacific events to be reported by a now forgotten machine - the telex) and one where the world media was content with the simple notion of a dashing lieutenant colonel saving his paradise nation from avaricious aliens. While the media were content with the glib, the regional politicians, not least Rabuka himself, found themselves in a cul-de-sac. International opinion, which was given to tolerating third world coups and disorder, was heading into a new globalization, and in 1991 this climaxed with the Harare Commonwealth 
Declaration that was supposed to be the new benchmark for democracy. That host Robert Mugabe notoriously failed to honour the document is beside the point; Fiji, which actually cared about the Commonwealth despite being treated badly by it, faced the prospect of severe isolation, on the sports field in places like New Zealand, in the Commonwealth Games and in the wider social world that the Commonwealth organization provides across professions and interests. Isolation could only be avoided in the new post-Harare age with democracy for all citizens, not just the indigenous ones. To his credit, Rabuka recognized the problem he had created with his coup and began to move away from the Taukei nightmare. This led to what was, at least for the 2006 election, the seminal event: the drawing up of what became the 1997 constitution by a former speaker, the late Tomasi Vakatora, academic Brij Lal and former New Zealand Governor General Sir Paul Reeves. The last, an indigenous Maori, said soon after the report was tabled that the terms of reference the three had been given were 'amongst the more significant political statements Fiji had made in quite a long time'.

Rabuka, then prime minister, and the then opposition leader, Jai Ram Reddy, accepted many of the constitutional proposals, particularly the introduction of open seats and the new alternative voting system, and Reeves believed that what they came up with was the route away from communal politics. ${ }^{1}$ Rabuka tabled the report in parliament on 10 September 1996 and on that day I wrote that it was 'a poignant way of bringing to an end the indigenous dream' that had ignited his coups nine years earlier. One line in the report got a lot of attention: '... trying to keep a predominantly Fijian Government in office in perpetuity may not be the best way of securing the paramountcy of Fijian interests'.

Then president Ratu Sir Kamisese Mara spoke to the joint session and, in a theme that has haunted Fijian politics since, he said traditional Fiji had a procedure for reconciliation. As in other Polynesian cultures, the business of saying sorry has always been deeply ingrained and much honoured, but the problem with the president's remarks was that he did not say who was meant to apologize to whom, and for what.

International media interest in Fiji's constitutional debate was limited mostly to how Rabuka would handle it - and, indeed, there was an element of surprise in his approach to the general election in 1999, the first under the 
new system and one in which the key players involved in the 1987 coup were active participants. Reddy and Rabuka were in an alliance around the new constitution, but the result suggested both Indian and indigenous voters were unimpressed by the coalition. In racially charged Fiji elections, such an artificial alliance was unacceptable to the majority, and the voters punished Rabuka and Reddy accordingly.

The scale of the Fiji Labour Party victory was a genuine international shock and the elevation of bruising trade unionist Mahendra Chaudhry to the top office quickly led to speculation on 'the next coup'. As argued in Speight of Violence ${ }^{2}$, the Fiji media had a role in creating the environment that led to the 2000 Speight coup. The Rupert Murdoch-owned Fiji Times, then under particularly intellectually barren editorial leadership, engaged in unethical, unsourced and frequently wrong scandal-mongering about the Chaudhry government. Chaudhry was right at the time: 'Since taking office, my government has had occasion to be extremely disgusted by the antics of some elements in the media who have used the medium of the newspaper and television to further their own personal agendas to discredit the government'.

And so, as Chaudhry prepared to cut the first birthday cake for his government on 19 May 2000, Speight and his thugs were coming through the front door in a bid to seize power and kill off multiculturalism. For a time they succeeded, although the partial success of the subsequent 2001 election, and the real achievement of the 2006 election, suggest the people of Fiji are learning.

Naturally, the Speight coup - if that is what it was and many doubts still remain after successive treason trials - remains a defining political event for Fiji. But, within the context of the 2006 election, it was intriguing that the single most influential event was that which occurred 10 days after Speight charged into parliament - Commodore Bainimarama's declaration of martial law; an event which needs to be redefined now as a coup, and one eminently more successful than the hair-brained effort mounted by Speight. One casual piece of evidence for this occurred during the 2006 election: Speight was shipped over from Nukulau to appear as a witness in court and only the small overseas media corps thought it was worth staking out. But when the Commodore spoke, the nation was given to holding its breath. 
During the afternoon and into the evening of 29 May 2000, a series of events occurred that climaxed with Ratu Sir Kamisese Mara stepping down as president and Commodore Bainimarama declaring martial law. The behaviour of those involved in this, which included Rabuka and the impotent Police Chief Isikia Savua, has - six years on - not been fully explained. On the face of it, the Commodore had staged a coup of his own and, while he was no more successful at resolving the hostage drama at parliament than Speight, he had all the trappings and advantages of power - including military power. His key action was something he did not do - restore Mr Chaudhry to power. This single absence of action has resulted in the Fiji we see today.

Quite early in the piece, the Commodore saw himself not only as the saviour of the nation, but also its grand director who would define its future according to a philosophy that was only accessible to his inner circle. It was a kind of military order that plays well on the poop deck. His 'order of battle' had him plucking an obscure senator and banker from Lau, Laisenia Qarase, and making him interim prime minister. It was never said explicitly, but was understood in those dark days of 2000, that Qarase was a caretaker, a stop-gap that would make long-term military rule of Fiji play well in the Commonwealth (Fiji is, ironically, one of the few ex-colonies that cares about that faded institution) and amongst the neighbours. The Commodore was not interested in a return to democracy, although he was to find out soon enough that in Wellington and Canberra that was all they were interested in.

Before the 'new military order' could be put in place, catastrophe struck, with a mutiny at the Queen Elizabeth Barracks on 2 November 2000. Eight men died, some tortured to death by loyal troops in what amounted to a bid to take out the Commodore, either dead or alive. At the time, the arrival on the scene of Rabuka, his uniform in the car and cell phone in his hand, was seen as little more than comedy and a media moment. He gave international radio interviews from the scene, gunfire crackling in the background. Only later did allegations arise that Rabuka was not the jester, but the organizer. These allegations were to splutter on for years, and at one point spoiled his chance of becoming Fiji's US ambassador. But he was not arrested until right in the middle of the 2006 election. 
International pressure for a return to democracy saw Fiji go to the polls in 2001 and, to the chagrin of the Commodore, his stand-in appointee suddenly formed a rag-tag party, the Soqosoqo Duavata ni Lewenivanua (SDL), and top-polled in the ballot. To form a government though, Qarase was obliged to make an alliance with those the Commodore regarded as his enemy, the Conservative Alliance that had successfully run George Speight as a candidate. As Speight was serving life on Nukulau, he could not take his seat.

In understanding what happened in 2006, it's important to recognize the biggest failing of the 2001 election process: the failure to form a multi-party cabinet, as required by the constitution. This, and the debilitating process of court action over it, was to sap Fiji in more ways than people recognized at the time. In the increasingly tedious and legalistic action, Mahendra Chaudhry traded off most of the goodwill he had earned as a hostage. He went from martyr to international bore in short order.

It was the Promotion of Reconciliation, Tolerance and Unity Bill and the Commodore's extreme reaction to it that turned Qarase's first term in office into a see-sawing voyage of uncertainty. At several points, the Commodore, plainly awash in his belief that he was the nation's saviour, threatened to do it all again and remove the Prime Minister from office. The inability of Qarase to act against the Commodore, who enjoyed tacit, if limited, support from President Ratu Josefa Iloilo, prolonged Fiji's political pain. Rather than protect Fiji from the traitors and the coup-plotters, the battle between the two created a deep political malaise and consequently had an impact on the government's ability to carry the country forward.

Another burst of activity from the Commodore in early 2006, and claims that other senior officers were plotting against him, finally pushed the government to a slightly earlier than expected general election. All the ghosts of 2000 were conspiring again: Bainimarama, like some Superman in a phone booth, was again ready to save the nation. As was explored in Speight of Violence, the military mounted an advocacy program which looked, at best, suspiciously hostile toward SDL. The message it offered was implicit: out of the 2000 coup came disorder, chaos, death and, by the way, SDL and its supporters. That the Commodore had got things so wrong took a while to sink in, not least because 
most of the population was smart enough to recognize that, while the military had helped cause the problems, their prime minister had put an end to them. But several factors counted against Bainimarama, not least a palpable if poorly documented weariness in the wider community. National saviours are good in their place, but not as a substitute for democracy. Bainimarama was showing signs of homespun megalomania.

The country moved into its immensely complicated election system, under the less than adequate leadership of Election Supervisor Semesa Karavaki. In his defence, though, an outsider can readily recognize that Fiji's poorly resourced voting process is always going to be a mess and of no attraction at all to anybody with real skills. The 2001 election under then supervisor Walter Rigomoto was regarded much later as somewhat more successful; Rigomoto, though, was exhausted by it all and was not interested in taking his skills onto the next election. Whatever Karavaki learnt in the 2006 election will mostly be lost to the 2011 ballot; he, too, found the process thankless.

The media approached the election in a post-coup mode, although few involved in the day-to-day coverage had even reported the 2000 coup, such is the high turnover in the domestic Fiji media. The three dailies provided a mishmash of stories about problems around the country, but with no coherent wrap. It was all tree-counting without seeing the forest. Fiji TV, other than providing a platform for a somewhat confused leaders debate, was given to providing lots of numbers but no pattern. When it came to announcing results during the three days of counting, they were often reluctant to break into programs such as Shortland Street. The real talent in election coverage this time around was found in radio, which seemed to have acquired a maturity it had not had in the coup or the last election. Stations, such as the English language Legend, plainly went into the election well-briefed and ready to devote considerable resources to the business of election coverage. The international media was distinctly uninterested in what was going on, and only a handful of the journalists - mostly representing news agencies - turned up. Just one or two had been in Fiji for any other election, much less the coups. Radio New Zealand established the pattern of leaning heavily on Fiji Radio's Legend, its solitary correspondent reduced to taping Legend. Auckland-based Radio Tarana, an AM radio station targeted at the Indian community, weighed into 
the election coverage scene with a big team, including Riyaz Sayed-Khaiyum. Although he had been living in Auckland for two years, his long stint with Fiji TV's Close Up program - including one broadcast during the coup that had prompted Speight's gang to trash the television station - meant he retained strong local respect. The shame was that the effort was targeted at a largely irrelevant audience.

The 2000 coup kept breaking into the election campaign in a variety of ways, some of which had to do with the capacity of the Fiji and foreign media to keep re-spinning conspiracy yarns. It was easily done, in large part because of a very low institutional memory when it comes to matters Fijian. A smalltime ex-soldier, Maciu Navakasuasua, who, like many others, served time in gaol for his role in the coup, demonstrated this particular failing. Sometime later he got some form of religion, moved to Australia and started making claims about what really happened in the coup. Most of it was recycled and had come out in the various trials earlier on, but the Fiji Sun and Australia's Graham Davis of Channel Nine acted as if it was all startling and new. It was particularly centred around claims that nationalist politician Iliesa Duvuloco had played a key role in the organization of the coup. Two years after his role had been revealed in court, it all popped up again. It had the extraordinary effect of giving Duvuloco, a five-times-failed politician, a kind of status and mana he was simply not entitled to. He had burnt the constitution on the steps of parliament when it was passed, and voters in election after election had steadfastly dismissed his brand of nationalism. This background was not provided by the media covering him and so, as a result of the media's fixation on short-term memory, he was elevated to some kind of anti-hero status. Happily, he managed to sink himself and his tiny Nationalist Vanua Tako Lavo Party with an appearance on Fiji TV's candidates' debate, chaired by Richard Naidu, when he seemed to lie in his chair almost flat, providing watchers with a view of his disproportionately bulky stomach. Voters were suitably unattracted.

Although the 2000 coup featured throughout the election campaign - largely as a result of the debate over the Promotion of Reconciliation, Tolerance and Unity Bill and the army's blundering efforts - during the calm week of voting the past was almost forgotten, until the Friday when, seemingly out of the blue, Rabuka was arrested on mutiny charges. That he was something of a 
relic was underscored by the way that his appearance in the Suva Magistrate's Court was almost casual; no additional security, no anxious supporters. He just strolled in to be greeted, mostly by journalists. An air of conspiracy seemed to hang around the timing, but Fiji Police Commissioner Andrew Hughes, on the afternoon after the court appearance, quickly dispelled the notion it was aimed at the election. The arrest timing, he said, had more to do with the fact that Rabuka had been in India having his knee caps replaced and had just come home. In the event, the arrest and court appearance proved merely to be a brief diversion in the election and had no obvious impact on its outcome. The High Court trial, still to come, might well prove much more threatening, potentially to the Commodore, whose distaste for Rabuka has been evident for a while. It has to be recalled that, on the night Bainimarama usurped power from Ratu Mara, Rabuka accompanied him. The Rabuka trial could well be a landmine yet to explode.

The protracted vote counting - a process no country the size of Fiji should willingly put itself through - was a dense affair, requiring observers to constantly run various equations through their heads. It got too much at times, even for people like Qarase who, at one point, told international media it was looking like he might lose. Only next day did he adopt a more positive demeanour and proclaim he had won. Chaudhry, as has always been his way, did not concede and nor did he offer congratulations. Fijian politicians are big on divisiveness.

Given the record, it was hardly surprising that much of the international media interest in the election was built around the possibility of a coup should Chaudhry return to power. It seemed to come as a genuine shock to discover that the one prospect of military action against an elected government would be against one led by Qarase. If one were to have taken place, it would most likely have occurred on 17 May, the day the Commodore re-emerged in one last desperate bid to produce an outcome he wanted. In a country given to action-packed days, that was one. Early that morning, Bainimarama was on Fiji Radio's Legend warning that the return of the SDL government did not 'auger well for the nation'.

Shortly after that comment, George Speight was briefly in Suva to appear in court and, as reporters waited, word came that Bainimarama would hold 
a press conference in his headquarters, just behind Government House. His body language and his demeanour throughout the press conference manifested agitation, confusion and anger. Asked repeatedly to rule out martial law or some kind of military action against the government, he preferred to play a dangerous game of claiming some higher duty to order and power. Bizarrely, he kept saying that elections and democracy were not a numbers game; and yet that is precisely what they were at that point. 'I prefer that the SDL don't come into government.... We are going to fight those bills if he brings them up again', the commander said. 'Take this message to the SDL party; we are going to fight them all the way.'

Bainimarama said that he hoped Qarase's government would provide the leadership the nation deserved, but added: 'the writing on the wall doesn't say that'. It was, though, a Parthian shot, as Qarase knew he had the numbers and an alliance ready to form government. The deals were sealed at a quickly called SDL caucus in a function room at JJs restaurant in downtown Suva. In the media huddle, Qarase was asked if he felt threatened by Bainimarama: 'I don't feel threatened by anybody, only God'.

By early afternoon he was at Government House being sworn in and, soon after, back at his less than grand office ready for the really big moment of the day. Without warning, and by way of surprise given the bitterness of 2001, Qarase popped out with a generous proposal for a multiparty cabinet - as required by the constitution.

And if Bainimarama, caught up in the last war he had fought, was not able to think ahead, Qarase spelled it out for him: 'He like everybody else should respect the parliamentary system and parliament is the supreme power of the land'. The comment was endorsed by the media. The Fiji Sun commented: 'He's gone too far this time. And the commander ... now has to go the full distance. He has to quit'. The Fiji Times noted that the military head:

...has become a danger and threat. That danger and threat have to be removed for the sake of the nation. And as his employer, it is the Government's task to do something about it quickly. No more pussyfooting around. The nation needs to move on.

It is too soon to believe that in the 2006 election the 'coup era' was buried. Too many of the participants are still around, but it is comforting to know that many of them are now in their 60 s, and many younger people have moved 
beyond the crude, opportunistic use of indigenous causes for political gain. Indeed, the defining influences for many who will be leaders at a community level in Fiji are today being learned on the streets of Baghdad and on the bloody convoys hundreds of Fijians ride each day in Iraq.

The elder generation - both Indian and Fijian - have failed their country in unseemly grabs for power over the years. What is striking in Fiji, and indeed across the South Pacific, is the way in which politics excludes the young and the dynamic for the most part. Politics in Fiji is about the clique, the club and the corrupt. The ineptitude of much of the political leadership has always been the sub-text for Fiji's 'coup politics'. The same old names every time. But 2006 offers hints it might be different this time: new people have come in, some are of a different political mould, and the world has certainly changed from the day Rabuka walked into parliament and took over.

Qarase, who always seemed to be an incidental character in the political history of 1987 to 2001, has exhibited strong personal growth, and the 2006 election has made him stronger - although paradoxically his mandate is weaker. The controversial 'Reconciliation Bill' will, no doubt, finally see some legal light, but its biggest advocates have gone from parliament. A new order is slowly emerging. As Qarese said at his post-election press conference:

This election outcome is consistent with what I've always said, that in promoting national reconciliation and unity in Fiji, it is not enough and, in fact, it is totally unrealistic to regard society in Fiji as nothing more than a collection of individuals with equal basic rights and freedoms. We have to recognize that we are a society of communities with differences in the way they look at their security and confidence in living in Fiji.

The task before me and government in the next five years is to dedicate ourselves to the service of everyone in our nation, irrespective of their political loyalties, their ethnicities and cultures.

\section{Notes}

1 The joint parliamentary select committee, however, reversed the proposal for 45 open seats and 25 communal seats, settling instead on only 25 open seats and 46 communal seats. The original proposal to use the alternative vote in three-member constituencies was also dropped in favour of its use in 71 single-member constituencies.

2 Field, M., Baba T. \& Nabobo-Baba, U. 2005. Speight of Violence. Reed Publishing, Auckland. 